\title{
Genetic variation in the feeding value of alfalfa genotypes evaluated from experiments with dairy cows
}

\author{
JC Émile $^{1 *}$, M Mauries $^{2}$, G Allard $^{3}$, P Guy $^{1}$ \\ 'Station d'amélioration des plantes fourragères, Inra, 86600 Lusignan ; \\ ${ }^{2}$ Ecole supérieure d'agriculture, BP 748, 49007 Angers, France ; \\ ${ }^{3}$ Département de phytologie, université Laval, Sainte-Foy, PQ GIK 7PA, Canada
}

(Received 16 December 1996 ; accepted 18 February 1997)

\begin{abstract}
Summary - An alfalfa (Medicago sativa L) with improved digestibility, 6328P, was fed to dairy cows in order to determine the effects of its nutritive value on milk production. Three different trials lasting 20, 9 and 16 days were conducted on two groups of ten dairy cows each. Animals were fed either the $6328 \mathrm{P}$ alfalfa or the widely used alfalfa variety, Europe. Alfalfa quality and its intake as well as milk production and milk fat and protein contents were recorded. The $6328 \mathrm{P}$ alfalfa had a higher leaf/stem ratio and a higher crude protein content than Europe. In vitro as well as in vivo digestibilities increased by $1-9 \%$ for the $6328 \mathrm{P}$ alfalfa compared with Europe. With $6328 \mathrm{P}$, alfalfa intake increased by $12 \%\left(1.9 \mathrm{~kg} \mathrm{~d}^{-1}\right)$, while milk production was raised by an average of $7 \%\left(1.4 \mathrm{~kg} \mathrm{milk} \mathrm{d^{-1 }}\right)$. This overall increase in milk production was responsible for increased milk fat and milk protein yields despite a lower fat content and only a slightly higher protein content in the milk produced by cows fed the 6328P alfalfa. Clearly genetic variability in the nutritive value of alfalfa exists, and using this variability will improve dairy cow performance.
\end{abstract}

alfalfa / digestibility / nutritive value / dairy cows / milk yield / intake

Résumé - Variabilité génétique de la valeur alimentaire chez la luzerne en affouragement de vaches laitières. Un génotype expérimental de luzerne (Medicago sativa L), 6328P, a été utilisé en affouragement de vaches laitières, en comparaison avec la variété Europe, pour mesurer les effets d'une amélioration génétique de la digestibilité sur la production de lait. Trois essais, d'une durée de 20,9 et $16 \mathrm{j}$, ont été successivement réalisés en utilisant pour chaque essai deux groupes de vaches laitières comportant dix animaux chacun. Les animaux ont été alimentés soit avec le génotype de luzerne 6328P soit avec le cultivar Europe. Dans chacun des trois essais, le génotype 6328P avait un ratio feuille/tige plus élevé, une teneur en protéines plus élevée et une teneur en fibres brutes plus faible que le témoin Europe. De même, les valeurs de digestibilité in vitro et in vivo étaient de 1 à $9 \%$ plus élevées pour le génotype $6328 \mathrm{P}$. Les quantités ingérées de luzerne étaient augmentées de $12 \%\left(1,9 \mathrm{~kg} \mathrm{jour}^{-1}\right)$, et la production laitière augmentée en moyenne de $7 \%\left(1,4 \mathrm{~kg}_{\text {lait jour }}{ }^{-1}\right)$ avec le génotype 6328P. Ce gain de production de lait a permis d'obtenir une augmentation de la production des matières grasses et protéiques, alors que le taux butyreux était plus faible pour les vaches alimentées avec la lignée 6328P, le taux protéique étant légèrement supérieur. Ces résultats montrent qu'il y a une variabilité de réponse zootechnique face à une variabilité génétique de la valeur alimentaire chez la luzerne, permettant et justifiant des démarches d'amélioration génétique de la luzerne à la fois pour des caractéristiques liées à la digestibilité, mais aussi à l'ingestibilité.

luzerne / digestibilité / valeur nutritive / production laitière / ingestibilité

Article communicated by Mike Hayward (Aberystwyth)

* Correspondence and reprints.

Tel: (33) 054955 25; fax: 0549556066 ; e-mail: emile@lusignan.inra.fr

Abbreviations: ADF: acid detergent fiber; DM: dry matter; DMI: dry matter intake; NDF: neutral detergent fiber. 


\section{INTRODUCTION}

Alfalfa is the most cultivated leguminous forage species in France, as a pure culture, and also in North America. It is well known for its agronomic qualities, including high productivity, symbiotic fixation of atmospheric nitrogen, improvement of soil fertility and soil structure, drought resistance and ability to trap deeply imbedded nitrogen. The significance of alfalfa as a high quality food supply for ruminant rearing has been recognized in many studies. Alfalfa is characterized by a high protein content, and its intake by animals is superior to that of grasses (Andrieu et al, 1988). However, its rather high structural carbohydrate content negatively affects its digestibility and the use of alfalfa in dairy cow rations has been declining in Europe for the past few years. It has been replaced by maize, chosen for its higher energetic content, and also for its better adaptation to soil conditions in areas where dairy cattle are bred.

With agriculture evolving towards a global market, farmers are being pressed to reduce their production costs. For dairy producers, improving the energetic food value of forage species like alfalfa could substantially reduce their feeding costs, which represent half the cost of milk production. To reach such a goal, better harvest controls (Nelson and Satter, 1990; Minson, 1990) or better conservation and distribution controls could be targeted; however, breeding improvements in a widely used forage species is still the most inexpensive way to succeed. Genetic variation in the digestibility of different alfalfa cultivars or species has been observed using measurements carried out in vitro (Thomas et al, 1968; Allinson et al, 1969; Buxton et al, 1987; Lenssen et al, 1988; Julier et al, 1996) in situ (Andrighetto et al, 1995) or in vivo (Thomas et al, 1968; Wilson et al, 1978; Guy et al, 1978; Minson, 1990). But the effects of such genetic variation on milk production has not been reported for alfalfa, despite evidence from other forage species such as maize (Barrière and Emile, 1990; Barrière et al, 1995), tall fescue (Emile et al, 1992) and a tropical grass, Digitaria milanjiana, (Lowe et al, 1991). The objective of the present study was to evaluate the effect of an improvement of alfalfa digestibility, and hence its energetic value, on the milk yield of lactating dairy cows, and thus to illustrate the value of genetic improvement of digestibility in alfalfa through breeding.

\section{MATERIALS AND METHODS}

\section{Experimental conditions}

An experimental alfalfa strain, 6328P, was compared to the variety Europe that is widely grown in France. This $6328 \mathrm{P}$ alfalfa strain and Europe have similar maturity dates but the experimental strain has a less erect habit and an increased leaf to stem ratio at a given phenological stage (Emile and Traineau, 1993). Forage yields of $6328 \mathrm{P}$ were $95 \%$ of the yields of Europe. Harvesting Europe at an earlier phenological stage could provide a similar forage quality, but would result in significant yield reductions and a decrease in persistence of the stand. Ingestion as well as in vivo digestibility by sheep of the $6328 \mathrm{P}$ strain were improved by 5 and $2.7 \%$, respectively. In vitro digestibility was $3.8 \%$ higher than the control strain.

The two alfalfa populations, 6328P and Europe, were grown on adjacent 2-ha plots at Inra Lusignan (Vienne, France). Growing conditions were similar for both plots. Plots received $1000 \mathrm{~kg} \mathrm{ha}^{-1}$ of lime before seeding in May 1989. A herbicide mixture of 2,4 D and dinosebe was used at seeding. Annual fertilization was carried out according to recommandations and consisted of $400 \mathrm{~kg}$ of $0-21-23\left(\mathrm{~N}-\mathrm{P}_{2} \mathrm{O}_{5}-\mathrm{K}_{2} \mathrm{O}\right)$ and $150 \mathrm{~kg}$ of $0-0-60$ per hectare. During the seeding year, the alfalfa was harvested as hay.

The two alfalfa populations were compared during three different growing periods: the first one lasted 20 days and began on 1 May 1990 (trial 1), the second one lasted 9 days from 7 June 1990 (trial 2) and the third one, 16 days from 2 May 1991 (trial 3). Therefore, for trials 1 and 3 , the first production cycles from each growing season were used. A portion of each of the 2-ha plots was cut and harvested on 1 May 1990 (first day of trial 1) and the forage used during trial 2 was the regrowth from these plot sections. For all trials, alfalfa forage was harvested daily and distributed to cows as greenchop. Within each trial, a later maturity stage was reached with time, from prebud to bud stage at the beginning of a trial to full bloom at the end. However, maturity stages were similar for the two alfalfa populations.

\section{Forage characteristics}

Once a week, a 3000-g sample from each alfalfa population was separated into leaf and stem, dried until constant weight and used to determine the leaf/stem ratio. Dry matter, in vitro digestibility using rumen juice (Tilley and Terry, 1963), crude protein (Kjeldahl) and crude fiber according to Weende (AOAC, 1970) were determined weekly on a composite specimen of forage samples harvested daily. While crude fiber is not as valuable as NDF and ADF to compare forages from different species or at different maturity stages, crude fiber is a good indicator of the energetic value of forage, especially 
when forages from the same species and at similar maturity are compared (Sauvant, 1988).

In vivo digestibility and ingestibility of alfalfa were assessed during each trial by concurrently feeding the forage to sheep. Two groups of six sheep were placed in digestibility crates and were fed exclusively one of the two alfalfa forages. For each sheep, the forage distributed, the amount refused and the faeces produced were determined daily. Forage dry matter intake was obtained by subtracting the refusal from the forage distributed. Total forage ingested minus dry matter recovered in the faeces gave the total dry matter digested, which when divided by the forage ingested provided the in vivo digestibility of organic matter. Weekly averages were then calculated

Forage net energy of lactation ( $\mathrm{mj}$ per $\mathrm{kg}$ ) was calculated according to Andrieu and Demarquilly (1987); their method uses the in vivo digestibility of organic dry matter, the crude protein and the crude fiber contents to determine the energy value, which could also be expressed in terms of the Net Inra energy value for milk production (UFL; $1 \mathrm{UFL}=7.106 \mathrm{mj}$ ).

\section{Animal characteristics and performances}

Prim'Holstein dairy cows with an average production of $7800 \mathrm{~kg}$ of milk per year were used. Cows calved in Autumn and were in the second half of their lactation period when the trials took place in the following Spring. After a 2- to 3-week reference period on pasture, the animals in the herd were paired as determined by their rank and stage of lactation, weight, milk yield, milk fat and protein content. Ten pairs of animals with very similar characteristics were selected and cows from each pair were assigned to two different groups. Each group of ten cows received only one alfalfa forage during a trial. The same group of animals were used for trials 1 and 2 . In each group, we had two heifers for trials 1 and 2 and three for trial 3. Animal characteristics at the beginning of each trial are presented in table 1.

Cows were housed free-standing and were fed alfalfa three times a day to insure adequate forage availability at 0900, 1500 and 2200 hours. Individual forage intake was registered daily using an electromagnetic door. The amount of alfalfa distributed was adjusted every day for each cow based on the previous day's consumption, therefore animals were fed at will and refusal was limited to $10 \%$. Alfalfa forage being distributed as greenchop, composition of the refusal was assumed to be similar to the forage distributed. While greenchop alfalfa is not widely used results can be transposed to stored forage methods such as hay or silage (Demarquilly and Andrieu, 1988). In order to fulfil the energy requirements of the animals, a concentrate rich in cereal (barley/corn/CaHPO $/ \mathrm{MgCl}_{2}, 60: 35: 5: 2.5$ ) was given individually at a ratio of $1 \mathrm{~kg}$ concentrate for 3 $\mathrm{kg}$ of milk produced above the theoretical milk production allowed by alfalfa ( $18 \mathrm{~kg}$ of milk for trials 1 and 3 , and $15 \mathrm{~kg}$ of milk for trial 2). The heifers received an extra $2 \mathrm{~kg}$ of this concentrate to fulfil their growing requirements.

Pre-trial periods varying between 10 and 15 days were used to familiarize the animals to the electromagnetic doors and to the alfalfa-concentrate diet. During these periods, the same alfalfa forage was served to both groups and forage intake was measured in the same manner as during the trial.

During trials, individual milk yields were recorded daily and milk protein and fat contents were determined four times a week. Animals were weighed on a weekly basis. The energy balance was estimated by calculating the differences between the animal's need (energy calculated for maintenance and milk production) and the energy supplied by the diet, taking into consideration the interactions between forage and concentrates.

Data were analyzed using the GLM procedure from SAS (SAS Institute, Inc., 1989). For each of the three trials, an analysis with repeated measurements (days) and two explanatory factors, alfalfa populations and animals, was used to study the criteria measured daily: milk yield and alfalfa intake. For each trial, data on alfalfa intake were corrected by means of a covariable analysis using data collected during the corresponding pre-trial period. To evaluate the effects of alfalfa populations on milk fat and protein contents, an overall analysis of the three trials was carried out. The average data from each trial with the animal effect

Table I. Animal characteristics at the beginning of each of the three trials.

\begin{tabular}{|c|c|c|c|c|c|c|}
\hline & \multicolumn{2}{|c|}{ Trial I } & \multicolumn{2}{|c|}{ Trial 2} & \multicolumn{2}{|c|}{ Trial 3} \\
\hline & Mean & $s d$ & Mean & $s d$ & Mean & $s d$ \\
\hline Days in milk (d) & 193 & 46 & 227 & 46 & 209 & 22 \\
\hline Milk yield $\left(\mathrm{kg} \mathrm{d}^{-1}\right)$ & 25.5 & 5.0 & 17.0 & 5.5 & 21.0 & 8.4 \\
\hline Milk fat $(\%)$ & 3.89 & 0.40 & 3.85 & 0.52 & 3.83 & 0.48 \\
\hline Milk protein $(\%)$ & 3.18 & 0.20 & 3.11 & 0.33 & 3.21 & 0.26 \\
\hline Body weight (kg) & 640 & 44 & 623 & 43 & 615 & 70 \\
\hline
\end{tabular}

$\mathrm{s} d$ : standard deviation. 
nested within trials were used for this analysis. An overall analysis was also carried out for alfalfa intake and milk yield.

\section{RESULTS AND DISCUSSION}

\section{Forage crops}

Characteristics of the $6328 \mathrm{P}$ alfalfa are comparable to previously published data (Emile and Traineau, 1993). At a similar maturity stage, the leaf/stem ratio is consistently higher for the 6328P alfalfa with a slightly lower dry matter content (table 2). Crude protein content is on average $2 \%$ higher and crude fiber content $3-4 \%$ lower for the 6328P strain compared to Europe. The in vitro digestibility is improved by $4-6 \%$. The higher quality of the $6328 \mathrm{P}$ alfalfa strain translates into an improved intake by sheep, from a $1 \%$ improvement for trial 1 to $9 \%$ for trial 3 . Concurrently, a higher in vivo digestibility of organic matter is observed. As a result, the net energy of lactation for the $6328 \mathrm{P}$ strain is 0.08 to $0.42 \mathrm{mj}$ higher than the one calculated for the variety Europe.

Throughout each of the three trials, forage quality decreased steadily with an average of $1 \%$ a week for in vitro digestibility (data not shown). These results are similar to previously reported data for alfalfa (Demarquilly and Andrieu, 1988; Conrad and Klopfenstein 1988). Although the $6328 \mathrm{P}$ strain produced a larger leaf/stem ratio, the decrease in forage quality was similar for both alfalfa populations. The length of the experimental trials may have been too short to observe any differential changes in quality with time between the two populations.

\section{Dry matter intake}

Alfalfa intake by dairy cows was high, ranging from 15.5 to $18.8 \mathrm{~kg}$ DM on average per day, depending on the trial and the alfalfa genotype (table 3). Including the concentrates, total intake in relation to animal weight (\% of $\mathrm{BW}$ ) varies from 2.89 to $3.20 \%$ for Europe and from 3.13 to $3.45 \%$ for the $6328 \mathrm{P}$ strain. These inter-group differences resulted from a significant $7-12 \%$ increase in alfalfa ingestion of the 6328P strain compared with Europe. Overall, the 6328P strain resulted in a significant $11.1 \%$ increase in DM intake (table 4).

The higher leaf/stem ratio can explain this increase in alfalfa intake. A greater proportion of leaves accelerates the digestive transit, as the leaves are more rapidly degraded in the rumen and less chewing is involved (Minson, 1990).

\section{Milk production}

According to the trial, daily milk production varied between 18.1 and $23.2 \mathrm{~kg}$ per day for the group fed with Europe and from 19.4 to $23.8 \mathrm{~kg}$ for the group with 6328P (table 3). Increases in milk production of $1.6,1.3$ and $0.6 \mathrm{~kg}$ per day were obtained for trials 1,2 and 3, respectively. The small increase in milk production in trial 3 is linked to difficulties in grouping the cows. At the beginning of trial 3, it became apparent that there was a difference in milk yield between the two groups. Since milk production was measured during the pre-trial periods, an analysis on yield differences (milk during the trial - pretrial milk) was carried out; it confirmed the superiority of

Table II. Morphological and chemical compositions, intake, in vivo digestibility and net energy value of two alfalfa populations.

\begin{tabular}{|c|c|c|c|c|c|c|}
\hline & \multicolumn{2}{|c|}{ Trial 1} & \multicolumn{2}{|c|}{ Trial 2} & \multicolumn{2}{|c|}{ Trial 3} \\
\hline & Europe & $6328 P$ & Europe & $6328 P$ & Europe & $6328 P$ \\
\hline Leaf/stem ratio $(\%)$ & 0.81 & 1.11 & 1.39 & 1.66 & 1.56 & 1.99 \\
\hline Dry matter $(\%)$ & 18.8 & 17.6 & 20.3 & 18.5 & 17.9 & 17.8 \\
\hline Crude protein (\% DM) & 18.4 & 20.0 & 18.2 & 21.0 & 18.6 & 20.3 \\
\hline Crude fiber (\% DM) & 33.2 & 28.0 & 31.1 & 27.6 & 26.7 & 23.6 \\
\hline In vitro digestibility (\% DM) & 60.5 & 66.2 & 63.4 & 67.7 & 64.4 & 69.2 \\
\hline Intake by sheep $\left(\mathrm{g} \mathrm{d}^{-1} \mathrm{~kg}^{-0.75}\right)$ & 67.7 & 68.8 & 74.5 & 79.8 & 72.9 & 82.1 \\
\hline In vivo digestibility of organic matter $(\%)$ & 65.5 & 66.4 & 66.4 & 68.7 & 68.8 & 71.4 \\
\hline Net energy of lactation $(\mathrm{mj})$ & 5.53 & 5.65 & 5.36 & 5.78 & 5.95 & 6.24 \\
\hline
\end{tabular}


the 6328P alfalfa with a probability level of 0.12 (data not shown). For the three trials combined, a significant increase of $1.35 \mathrm{~kg}$ of milk per day as well as a higher milk production corrected for fat content was obtained with the $6328 \mathrm{P}$ alfalfa (table 4).

Fat content was lower and protein content higher in the milk produced by cows fed the $6328 \mathrm{P}$ alfalfa (table 3 ). Overall for the three trials, the decrease in fat content and the increase in protein content of the milk are not significant. However, the increase in milk production resulted in significantly higher fat and protein yields per cow per day (table 4).

\section{Energetic feed value of alfalfa}

Since body weights were similar for paired groups at the beginning of each trial, the small difference in average weight at the end of the trials (table 4) suggests that animals fed the $6328 \mathrm{P}$ alfalfa gained more weight. This could be related to differences in ingested nutrients since the $6328 \mathrm{P}$ alfalfa was better ingested and more digestible. However, the short length of the experimental trials prevents significant conclusions to be drawn on variation in cow weight during these trials. For this reason, variation in body weight was not used to estimate the nutritional energy balance. This could slightly
Table IV. Overall analysis of the average individual zootechnical performances of cows fed with two different alfalfa populations during three trials.

\begin{tabular}{llll}
\hline & Europe & $6328 P$ & Fvalue \\
\hline Alfalfa DMI $\left(\mathrm{kg} \mathrm{d}^{-1}\right)$ & 16.20 & 18.05 & $44.2^{* * * *}$ \\
Milk yield $\left(\mathrm{kg} \mathrm{d}^{-1}\right)$ & 21.05 & 22.40 & $18.3^{* * *}$ \\
FCM 4\% $\left(\mathrm{kg} \mathrm{d}^{-1}\right)$ & 20.24 & 21.48 & $10.0^{* *}$ \\
Milk Fat $(\%)$ & 3.79 & 3.71 & $1.4^{\mathrm{ns}}$ \\
Milk Protein $(\%)$ & 3.13 & 3.16 & $0.6^{\mathrm{ns}}$ \\
Fat Yield $\left(\mathrm{kg} \mathrm{d}^{-1}\right)$ & 0.79 & 0.83 & $4.7^{*}$ \\
Protein Yield $\left(\mathrm{kg} \mathrm{d}^{-1}\right)$ & 0.66 & 0.70 & $14.9^{* *}$ \\
Body Weight $(\mathrm{kg})$ & 628 & 634 & $0.1^{\mathrm{ns}}$ \\
\hline
\end{tabular}

$*, * * * * *$ significant at $P<0.05,0.01$ and 0.001 , respectively. ${ }^{\text {ns }}$ not significant.

modify the interpretation of the energy balance data.

Considering the animals' needs, the nitrogen contents of both rations were high, especially when the cows were fed the $6328 \mathrm{P}$ alfalfa (table 3 ). These excesses, and the resulting wasted nitrogen, are not surprising since alfalfa was available ad libitum and it has a high protein content with a large proportion of degradable proteins.

Energy supply with the 6328P diet is superior to that of the Europe diet. A higher intake of the $6328 \mathrm{P}$ strain of $1.85 \mathrm{~kg} \mathrm{DM} \mathrm{d}^{-1}$ (table 4) associated with an improved net energy of lactation of $0.29 \mathrm{MJ} \mathrm{kg}^{-1}$ (table 2) accounts for

Table III. Alfalfa intake, milk production and composition, and total diet characteristics resulting from two alfalfa populations fed to dairy cows in three different trials.

\begin{tabular}{|c|c|c|c|c|c|c|}
\hline & \multicolumn{2}{|c|}{ Trial 1} & \multicolumn{2}{|c|}{ Trial 2} & \multicolumn{2}{|c|}{ Trial 3} \\
\hline & Europe & $6328 P$ & Europe & $6328 P$ & Europe & $6328 P$ \\
\hline Alfalfa DMI $\left(\mathrm{kg} \mathrm{d}^{-1}\right)$ & 15.5 & $17.4^{* *}$ & 15.9 & $17.6^{* * *}$ & 17.5 & $18.8^{*}$ \\
\hline Supplement DMI $\left(\mathrm{kg} \mathrm{d}^{-1}\right)$ & 2.7 & 2.7 & 1.2 & 1.2 & 2.3 & 2.3 \\
\hline Total DMI (\% of BW) & 2.89 & 3.13 & 2.98 & 3.20 & 3.20 & 3.45 \\
\hline Milk yield $\left(\mathrm{kg} \mathrm{d}^{-1}\right)$ & 22.1 & $23.7^{* * *}$ & 18.1 & $19.4^{* * *}$ & 23.2 & $23.8^{\mathrm{ns}}$ \\
\hline $\mathrm{FCM} 4 \%\left(\mathrm{~kg} \mathrm{~d}^{-1}\right)$ & 21.7 & 22.6 & 17.5 & 19.1 & 22.5 & 22.8 \\
\hline Milk fat $(\%)$ & 3.85 & 3.70 & 3.89 & 3.78 & 3.84 & 3.67 \\
\hline Milk protein (\%) & 2.99 & 3.16 & 3.09 & 3.22 & 3.13 & 3.17 \\
\hline Diet protein $(\%)$ & 15.7 & 17.3 & 16.9 & 19.7 & 16.4 & 18.1 \\
\hline Diet energy $(\mathrm{mj})$ & 101.7 & 118.1 & 92.1 & 108.0 & 119.3 & 131.5 \\
\hline Energy balance (mj) & -8.0 & +7.2 & -3.8 & +8.0 & +7.1 & +20.9 \\
\hline
\end{tabular}

$*, * *, * * *$ within row and trial values are significantly superior at $P<0.05,0.01,0.001$, respectively. ${ }^{\text {ns }}$ within row and trial no significant difference at $P<0.05$. 
the higher energetic values of the 6328P diet (table 3 ). With an average gain in milk production of $1.24 \mathrm{~kg}$ of $4 \%$ fat corrected milk with the $6328 \mathrm{P}$ diet (table 4), the marginal efficiency is 84 $\mathrm{g}$ of milk per supplementary mj in the diet. This result is well within the range of known values when the energy needs of the animals are satisfied.

\section{CONCLUSION}

Genetic variation, for in vitro digestibilities and for in vivo digestibilities and intake by standard animals, in alfalfa fed to dairy cows clearly affected their performances. The improved alfalfa has value in terms of a better intake by animals, which translates into higher milk production. The superiority of the $6328 \mathrm{P}$ probably results from the combined effects of a higher leaf proportion in the total forage biomass, as highlighted previously (Guy et al, 1978; Hill et al, 1988; Kephart et al, 1990; Lemaire et Allirand, 1993) and higher digestibility of stems (Buxton et al, 1987; Lenssen et al, 1988; Jewett et Barnes, 1992). A recent study by Emile et al (1996) reports similar improvements in dairy cow performances using the $6328 \mathrm{P}$ alfalfa as a dehydrated supplement to corn silage diets. As a result, it appears that selection for improved digestibility of forages is possible and would result in better animal performances. As broad genetic variation seems to be available within the Medicago sativa complex (Julier et al, 1996), plant breeders should be able to exploit these characteristics without neglecting other constraints, such as cold tolerance, resistance to lodging and to diseases, seed production and maintaining dry matter yield (Hill et al, 1988).

Greenchop forage eliminates the problems of choice observed in pasture trials and is useful to display differences in quality (Conrad and Klopfenstein, 1988). These trials undertaken in extreme conditions, with alfalfa as the only forage, suggest that alfalfa varieties of better quality can be offered to dairy producers in the near future (Emile et al, 1996).

\section{ACKNOWLEDGEMENTS}

The authors wish to thank R Seoane (Québec) and $Y$ Barrière (Lusignan) for revision of the manuscript.

\section{REFERENCES}

Allinson DW, Elliot FC, Tesa MB (1969) Variations in nutritive value among species of the Medicago genus as measured by laboratory techniques. Crop Sci 9, 634-637

Andrieu J, Demarquilly C (1987) Valeur nutritive des fourrages : tables et prévisions. Bull Tech CRZV Theix, Inra 70, 61-73

Andrieu J, Demarquilly C, Sauvant D (1988) Tables de la valeur nutritive des aliments. In : Alimentation des Bovins, Ovins et Caprins (R Jarridge, ed), Inra, Paris, 356-443

Andrighetto I, Cozzi G, Magni G, Hartman B, Hinds M, Sapienza D (1995) Comparison of in situ degradation kinetics of lucerne germplasm by ANOVA of non-linear models. Anim Feed Sci Technol 54, 287-299

Association of Official Analytical Chemists (1970). Official Methods of Analysis, 11 th ed. AOAC, Washington, DC.

Barrière Y, Emile JC (1990) Effets des teneurs en grain et de la variabilité génétique sur la valeur énergétique du maïs ensilage mesurée par des vaches laitières. agronomie 10, 201-212

Barrière Y, Emile JC, Traineau R, Hébert Y (1995) Genetic variation in the feeding efficiency of maize genotypes evaluated from experiments with dairy cows. Plant Breeding 1 14, 144-148

Buxton DR, Horstein JS, Marten GC (1987) Genetic variation for forage quality of alfalfa stems. Can $J$ Plant Sci 67, 1057-1067

Conrad HR, Klopfenstein T (1988) Role in livestock feeding - greenchop, silage, hay, and dehy. In: Alfalfa and Alfalfa Improvement (AA Hanson, DK Barnes, RR Hill, Jr, eds), Monogr 29, Am Soc Agron, Madison, WI, 539-551

Demarquilly C, Andrieu J (1988) Les fourrages. In : Alimentation des Bovins, Ovins et Caprins ( $\mathrm{R}$ Jarridge, ed), Inra, Paris, 315-336

Emile JC, Gillet M, Ghesquière M, Charrier X (1992) Pâturage continu de fétuques élevées par des vaches laitières : amélioration de la production par l'utilisation d'une variété sélectionnée pour l'appétibilité. Fourrages 130, 159-169

Emile JC, Traineau R (1993) Effet de la variabilité génétique sur la digestibilité in vivo de la luzerne. Fourrages 134, 251-254

Emile JC, Barrière Y, Mauriès M (1996) Effects of maize and alfalfa genotypes on dairy cow performances. Ann Zootech 45, 17-27

Guy P, Huguet L, Sauvion A, Traineau R (1978) Breeding alfalfa for quality and protein yield. In: Proc 2nd Int Green Crop Drying Congr, Saskatoon, 142-147

Hill Jr, RR, Shenk JS, Barnes RF (1988) Breeding for yield and quality. In: Alfalfa and Alfalfa Improvement (AA Hanson, DK Barnes and RR 
Hill, Jr, eds), Monogr 29, Am Soc Agron, Madison, WI, 809-825

Jewett J, Barnes RF (1992) Variability for stem anatomy among entries in the perennial Medicago core collection. In: Rep 33th $N$ Amer Alfalfa Improv Conf 1992 Atlanta

Julier B, Guy P, Castillo-Acuna C, Caubel G, Ecalle C, Esquibet, Furstoss V, Huyghe C, Lavaud C, Porcheron A, Pacros P, Raynal G (1996) Genetic variation for disease and nematode resistances and forage quality in perennial diploid and tetraploid lucerne populations (Medicago sativa L). Euphytica 91, 241-250

Kephart KD, Buxton DR, Hill RR (1990) Digestibility and cell wall components of alfalfa following selection for divergent herbage lignin concentration. Crop Sci 30, 207-212

Lemaire G, Allirand JM (1993) La luzerne : ses potentialités, ses atouts et ses limites. Fourrages 134, 183-198

Lenssen AW, Sorensen EL, Posler GL, Harbers LH (1988) Forage quality of perennial glandularhaired and eglandular Medicago populations. Crop Sci 28 , 168-171

Lowe KF, Moss RJ, Cowan RT, Minson DJ, Hacker JB (1991) Selecting for nutritive value in Digitaria milanjiana: milk production from an elite genotype compared with Digitaria eriantha spp pentzii (pangola grass). Aust J Exp Agric 31, 603-608

Minson DJ (1990) Forage in Ruminant Nutrition. Academic Press Inc, San Diego, CA

Nelson WF, Satter LD (1990) Effect of stage maturity and method of preservation of alfalfa on production by lactating dairy cows. J Dairy Sci 73, 1800-1811

SAS Institute, Inc (1989) SAS/STAT ${ }^{\circledR}$ User's Guide: Statistics. Cary, NC

Sauvant D (1988) Composition et analyse des aliments. In : Alimentation des Bovins, Ovins et Caprins (R Jarridge, ed), Inra, Paris, 305-314

Thomas JW, McCampbell JL, Tesar MB, Elliot FC (1968) Improved nutritive value of alfalfa by crossing and selection based on in vitro methods. $J$ Anim Sci 27, 1783-1784

Tilley JMA, Terry RA (1963) A two-stage technique for the in vitro digestion of forage crops. I Brit Grassl Soc 18, 104-111

Wilson TR, Kromann RP, Evans DW (1978) Nutrient digestibility, digestible energy and metabolizable energy and agronomic data for five varieties of alfalfa hay. J Anim Sci 46, 1351-1355 